\title{
ロ之津地区に打ける表層地すべりの発生機構
}

\section{Studies on the Occurrence Mechanism of Surface Landslide in Kuchinotu Landslide area}

\section{玉 田 文 吾* \\ Bungo Tamada}

The relation between the creep upper yield stress $\tau_{u}$ of cohesive soil near the landslide face and the effective overburden pressure $p_{\varepsilon}$ on the landslide face can be expressed as follows:

where $c_{c}, \phi_{c}$ are coefficient.

$$
\tau_{u}=c_{c}+p_{e} \tan \phi_{r}
$$

A factor of the development of surface landslide in the region of Kuchinotu is the heavy rains amounting to over $250 \mathrm{~mm}$. That is, the decrease of effective overburden pressure due to the generation of pore water pressure of artesian condition from the ground water flows in permeable sandstone layers or conglomerate layers is the cause for the decrease of upper yield stress, and landslide is caused by the creep breakage of cohesive soil.

After landslide occurred, when the static water pressure due to ground water in the slideface has over constant value by the heavy rains, the slide of layer begins again.

\section{1. まえがき}

長崎県南高来郡口之津町一帯にかけて発生するロ之津 地すべりの概要については報告したことがあり1)。主と して地すべりの素因について言及した。この地区は地す ベり面の下位に透水性のよい砂（砂岩），砂磁（礫岩） の厚い互層が基盤を構成して和り，豪雨によって新規の 地すべりが発生したり，再滑動が繰返されたりしてい る。

この地区の地すべりは一般に規模が小さく, 滑動面積 0.5ha 以下のものは全体の $54 \%$, すべり面長 $50 \mathrm{~m}$ 以下 のものは70\%を占めている。またすべり面が浅いことも 特徴で, 深度 $3 \mathrm{~m}$ 以内は $49 \%, 3 \sim 5 \mathrm{~m}$ にすべり面をも つ地区は全体の $30 \%$ に達し，すべり面傾斜は大部分が $5^{\circ}$ 〜 $15^{\circ}$ となっているので, これらの地すべりのらち地す ベり面深度の浅いものを“表層地すべり”之呼称してい る。

ロ之津地すべりの誘因については，これまで降雨によ る間げき水圧の増加，または豪雨による地表面の侵食に もとづく受働土圧の減少として考えてきた が2)，表層地すべりの場合には被圧的な間 げき水压す考慮に入れなければ発生機構を 説明することが難しい。そこで基盤中の透 水層と被圧間げき水圧との関係を地質棈造 との関係から追跡した結果，特別な地区に 被圧地下水発生層が形成されていることが 見いだされた。加えて潜在地すべり面付近

西日本工業大学
のクリープ的破壞機構が判明したので，豪雨による新規 地すべりの発生機構があさらかになった。これらについ て検討したのが本報文である。

\section{2. 被圧地下水発生層}

\section{1 砂岩, 碃岩の特性}

口之津町周辺に扔いて地すべりが発生している地区の 地層は，第四紀更新世拉よび新第三紀中新世〜鮮新世に 属する口之津層群上部大屋層または下部大屋層で市る。 地すべり地区の基盤層（地すべり層序の第 III 層）は発達 した砂岩，碟岩，砂質碟岩などの互層からなるが，部分 的に泥岩，火山砕首岩をはさんでいて，その一部は高位 の場所に扣いて玄武岩類のキャップロックに被覆されて いる。地すべり面は基盤上部（地すべり層序の第 I 層特 よび第 II 層）にあり，基盤は滑動しないがつざのような 地質学的，物理的両特性をもっている。

（1）図-1は口之津町大报地区に扩ける地尿断面図で ある。ここは滑動面積 0.4 ha の小規模な地すべりである が，基盤は堆積相の变化が大きく，層厚の变化に富むレ

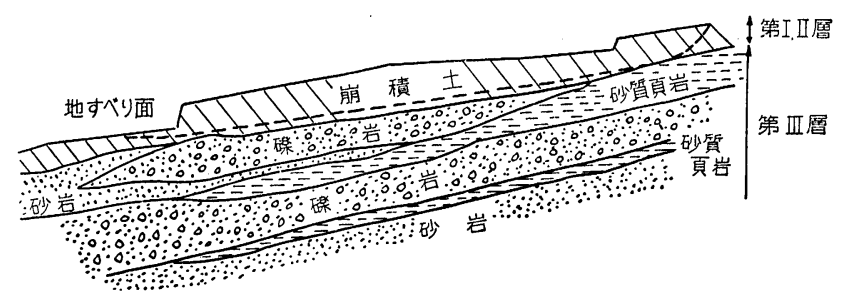

図-1 表層地すべり地区に打ける地層断面㘡 
ンズ状単層も見られ，各層の粒度構成には方向性があっ て勂所ごとに物理的性質が異なっている。この地区では 鍵層（兏石と言われている軽石質凝灰岩）に扣いても欠 層が見受けられる。

（2）第 I 層，第 II 層直下の砂岩と磻岩とは固結度が低 く砂または砂磁の状熊を呈している。砂の大部分は中粒 砂または粗砂で構成され，堆程縞（層理）または分級作用 による葉理面を留め, 場所によっては若干のシルト分を 含有する。砂磁は古期岩類の硬質円磁を含有する層で分 級作用がよく，下位から上位に向って粗粒から細粒にな る層相を呈するが，円嘫の欠除，砂，砂，シルトの搅拌 沈着帯など堆程相の変化が大きい。

（3） 口之津地区の基盤上部は以上述べたよらな性質の ため, 概して透水係数が大きく, 以前から地すべりと密 接な関係があることが注目され，各地内に沶いて多くの 透水試験が実施されてきた。この結果, 室内試験におい $\tau 10^{-2} \sim 10^{-3} \mathrm{~cm} / \mathrm{sec}$, 現㘯試験に沶いて $10^{-2} \sim 10^{-4} \mathrm{~cm} /$ $\sec$ の透水係数が報告されている3)。しかし堆積相の変 化が大きいため同一単層内に捺いても透水係数に相当の 差连がある。

\section{2 被圧地下水発生層}

たとえばロ之津町上大拔地内に执いては，砂，砂磁層 を流れる地下水の大部分は, 図-2 亿示すよ5に高位 部 にある玄武岩のキャップロックから流入する。したがっ て特定地凮条件のもとで水位差にほぼ等しい被圧地下水 になりこれが地すべり面に下部から直接作用する間げ き水圧を発生する。このような間げき水圧発生に加えて 口之津地区ではつぎのような水圧発生機構もある。

表-1 は 観 測用試錐孔の水位測定結果であるが，降雨 による水位変化の激しい場所とそらでない場所とがあ る。これは透水係数が大きくて地下水が流通しやすい部 分と, そうでない部分とがあることを示している。水 平, 垂直方向の透水係数の变化が, 漸移的ではあるが大 きい砂または礫層の中を, 一定量の地下水が流れると仮 定する。ここで透水係数の大きい部分が透水係数の小さ い部分によって周面が取り巻かれているときの状態を図 - 3 の 模 式図で表わすと, 砂の透水係数は間げき比に比 例するので, 同じ厚さ中の水平流に対して位置水頭を別

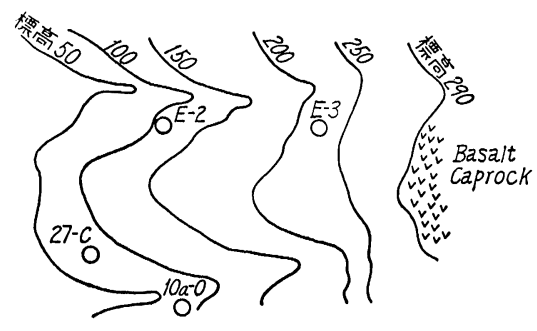

図-2 観湘井の位置と玄武岩のキャップロック
表-1 大抜地区観測井に拈ける水位測定

\begin{tabular}{c|r|r|r|r}
\hline \hline 剆 定 月 日 & E-2 & E-3 & $27-C$ & $10 a-0$ \\
\hline 4.10 & 4.55 & 39.55 & 4.50 & 3.70 \\
4.20 & 4.50 & 50 以下 & 6.15 & 2.05 \\
4.30 & 19.45 & 50 以下 & 8.15 & 2.40 \\
5.10 & 19.40 & 3.15 & 9.95 & 2.75 \\
5.20 & 8.45 & 9.60 & 3.15 & 2.10 \\
5.30 & 6.55 & 11.05 & 1.05 & 2.55 \\
6.10 & 6.05 & 4.60 & 1.00 & 1.85 \\
6.20 & 2.60 & 12.30 & 1.10 & 1.60 \\
6.30 & 9.30 & 8.20 & 2.45 & 2.45 \\
7.10 & 3.05 & 14.35 & 1.25 & 1.85 \\
7.20 & 2.75 & 14.35 & 2.15 & 2.10 \\
7.30 & 0.60 & 1.00 & 5.45 & 2.65 \\
8.10 & 2.80 & 14.00 & 5.40 & 2.40 \\
8.20 & 2.45 & 3.80 & 5.45 & 2.85 \\
8.30 & 14.40 & 11.25 & 6.75 & 2.70 \\
9.10 & 16.05 & 14.30 & 6.80 & 3.10 \\
\hline
\end{tabular}

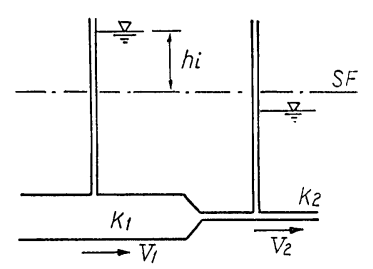

図-3 砂岩, 啋岩中の模式的地下水流

にすると, 有効断面積 $A$, 透水係数 $K$, 流速 $V$ の間に 式(1)の関係が近似的に成立する

$$
\left.\begin{array}{r}
K_{1}>K_{2}, \quad A_{1}>A_{2}, \quad V_{1}<V_{2} \\
p_{2}=p_{1}+\frac{1}{2} \rho \quad\left(V_{1}{ }^{2}-V_{2}{ }^{2}\right)
\end{array}\right\}
$$

したがって透水係数の大きい部分では水頭が高くなる ことが推定でき，図-3に拈いて地すべり面 S.F の位䐈 には $u_{i}=\gamma_{w} \cdot h_{i}$ 相当の水圧が作用し, これが被圧地下水 による間げき水圧になる場合がある。砂岩または磁岩層 において部分的に被圧地下水を発生するような機構をる つ層を “被圧地下水発生層”といら。このような層の存 在はつぎの事項から立証できる。

（1）新規の地すべりが発生した直後，地すべり地内に おいて地下水の自噴と, これにともなら砂の噴出現象が 見られ，これらの現象はつぎの条件のもとで発生する。

$$
u_{i}>\frac{G_{s}-1}{1+e} r_{w} \cdot d+p_{e}
$$

ここで, $G_{s}, e$ は砂の粒子比重と間げき比， $p_{e}$ は潜在 すべり面上の有効土かぶり応力とする。すなわち被圧水 圧 $u_{i}$ が作用し， $p_{e}$ の小さい場所に見られるが，このよ らな現像が発生するときの条件は，過去の統計によると 連続降雨量 $250 \mathrm{~mm}$ 以上のもとで引続さ $160 \mathrm{~mm}$ 以上の 日降雨量があったとさとされている4)。

（2）罒- 4 打よび表- 2 は下大拔地区で実施した地下水 追跡の結果である。調査孔に食塩を投入後，観測孔に拉 
表-2 大抜地区に打ける地下水追跡結果

\begin{tabular}{|c|c|c|c|c|c|}
\hline 採水地点 & 距 & $\begin{array}{l}\text { 示笅時間 } \\
(\mathrm{h})\end{array}$ & ${ }_{(\mathrm{m} / \mathrm{h})}$ & $\left|\begin{array}{c}\mid c ゙-ク \text { 時間 } \\
(\mathrm{h})\end{array}\right|$ & ${ }_{(\mathrm{m} / \mathrm{h})^{\text {度 }}}$ \\
\hline SG-4 & 231 & 1 & 231 & 129 & 1.79 \\
\hline 井戸-1 & 25 & 81 & 0.309 & 193 & 0.13 \\
\hline $29 \mathrm{~b}-1$ & 208 & 2 & 104 & 121 & 1.72 \\
\hline SG-1 & 162 & 9 & 18 & 97 & 1.67 \\
\hline $27-C$ & 119 & 79 & 1.506 & 105 & 1.13 \\
\hline 横孔-2 & 218 & 23 & 9.478 & - & - \\
\hline SG-3 & 156 & 45 & 3.467 & 97 & 1.61 \\
\hline $28 \mathrm{C}-2$ & 141 & 59 & 2. 390 & 105 & 1.34 \\
\hline 井戸-3 & 256 & 7 & 36.57 & 153 & 1.67 \\
\hline 井戸-2 & 104 & 9 & 11.56 & 121 & 0.86 \\
\hline $35 a-0$ & 208 & 1 & 208 & 105 & 1.98 \\
\hline $28 \mathrm{C}-0$ & 96 & 1 & 96 & 105 & 0.92 \\
\hline $28 b-0$ & 46 & 57 & 0.807 & 105 & 0.44 \\
\hline SG-2 & 209 & 1 & 209 & 105 & 1.99 \\
\hline
\end{tabular}

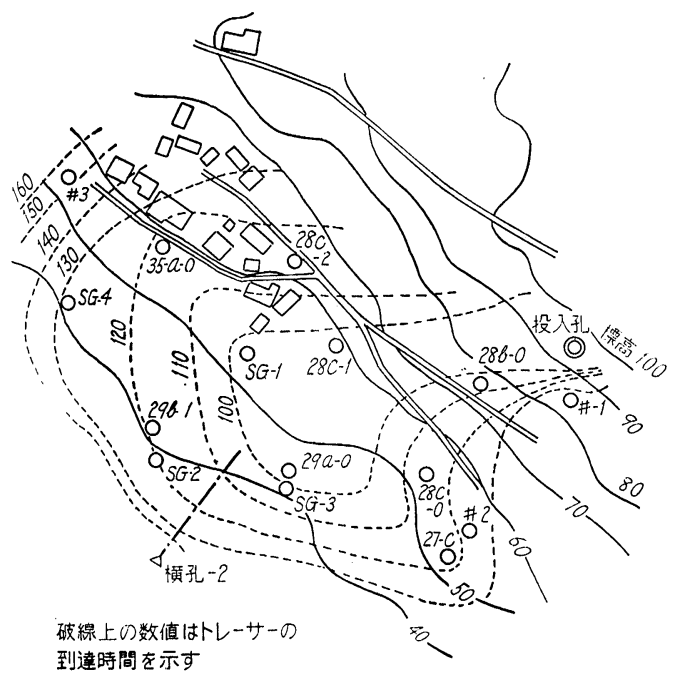

图-4 大抜地区に扰ける地下水追跡結果

いて食塩が検出されるまでの時間を測定したものである が，これによると西側の一部に打いて流速の大きい部分 があり，南拈よび南西に扔いては流速の小さい地区があ る。流速が小さい区内にある観測孔 No. 27-C 情-1 示したように降雨による水位変動が著しい。

（3）地すべり面拉よび water film 面観察のため地区 内にテストピットを掘削すると，すべり面上部には地下 水がなく，地すべり面下部から地下水が浸透または噴出 する現象が見られる。

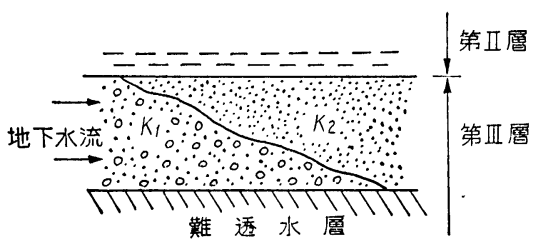

図-5被圧地下水発生層の模式旻
被圧地下水発生層はつぎの自然条件のもとで形成され やすい。すなわち図-5 の模式図に示したように，上位 が第 II 層の半透水層, 下位は固結度の高い難透水性の砂 岩または砂岩にはさまれた，ほぼ一定厚さの平面的な拡 がりをるつ透水層中を，さきに述べた気象状態のとき， ある時間だけ地下水の流通が継続する機構掞よび地層構 造でなければならない。このよらな層の平均厚さは $2 \mathrm{~m}$ 内外，傾斜は5以下の場合が多いようである。

\section{3.＼cjkstart表層地すべりの発生機構}

\section{1 口之津地区における地すべりの素因と誘因}

この地区の地表面付近は，第 I 層（玄武岩の転石を含 む崩積土），第 II 層（基盤岩類の強風化層），第層（基 盤岩類）の層序になっており，第 II 層の中には粘着力 $c_{w}=0.05 \mathrm{~kg} / \mathrm{cm}^{2}$, 内部摩擦角 $\phi_{w}=3^{\circ}$ 程度の超弱面である water film 面が多数含まれている5)。これらは四一 6 に示 すように，ある傾斜をもつ第 II 層内にランダムに並んで いるが，連続した面ではなく，これらの間には未破壊部

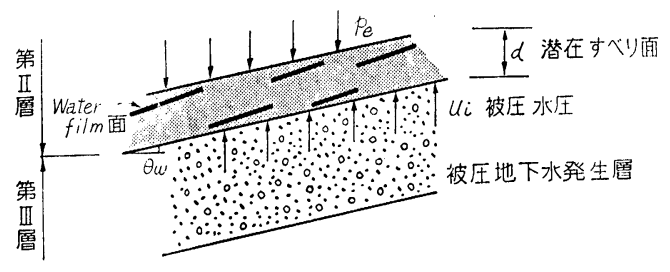

图-6 潜在すべり面に作用する被圧的間げき水圧

分がある。しかし多数の water film 面を含む部分は，他 の部分に比較すると弱部になっているため，これを“潜 在すべり面”之呼称して扔り6)，これが地すべりの素因 になっている。

つぎに誘因とは，潜在すべり面が連続した破壊面に転 化する原因，すなわち未破壊部分（不連続部分）が破壊 する原因である。未破壊部分の粘着力と内部摩擦角は口 之津地区に打いて $c_{2}=0.2 \mathrm{~kg} / \mathrm{cm}^{2}, \phi_{2}=23^{\circ}$ 程度（平均 值）であるが，未破壊部分がクリープ的破壊を拉こすと き，被圧地下水発生層の存在が誘因になるとすれば，こ れが未破壊部分のクリープ的破壊を促進していることに なる。したがって直下の第層が被圧地下水発生層であ る場合，既述の条件のもとで，ある期間内に被圧水圧 $u_{i}$ が発生すると，図-6の $d$ の部分が薄くて亀裂が多い場 合，あるいは若干の砂が混入して透水性がよい場合には 水压が伝達され易く，潜在すべり面上部には難透水層も あるので，図-6に示したよらに間げき水圧となって潜 在すべり面に直接作用する。要約すれば潜在すべり面に 被圧的間げき水圧が作用することが誘因の一つになる。

\section{2 間げき水圧発生による新規地すべりの発生機構}

図-7は water film 面間の未破壊部分に二次元応力が 


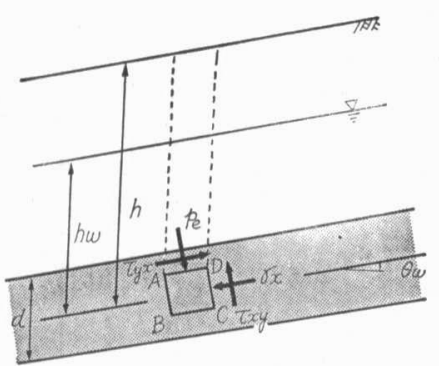

図-7 潜在すべり面中の未破壞部に作用する二次元応力

作用した場合について考えたものである。図に括いて $\sigma_{y}=\left(p_{e}\right)$ を垂直応力, $\sigma_{x}$ を水平応力とし, これに $\tau_{x y}$ $=\tau_{v x}$ なるせん断応力か゚加わるすのとする。このよらな 各応力が同時に働く場合, 図の $\mathrm{ABCD}$ 内部の最大主せ ん断応力 $\tau_{1}$ はつぎの式で表わされる。

$$
\tau_{1}=\frac{1}{2} \sqrt{\left(\sigma_{x}-\sigma_{y}\right)^{2}+4 \tau_{x y}^{2}} .
$$

したがって $\tau_{1}$ が未破壊部分のせん断強度 $\tau$ に達する と破壞が発生することになるが，未破壞部分のせん断定 数 $c_{2}=0.2 \mathrm{~kg} / \mathrm{cm}^{2}, \phi_{2}=20^{\circ} 10^{\prime}$ （たと党ば表- 4 の数值） を用いて計算したのでは理論上破壊しないことになる。 しかるに破壊しないはずの未破壞部分が容易に破壊する 事実を考えると，すでに述べたようにクリープ破壊を含 む特殊な破壊形式によるるのと考えざるを得ない。

このために未破壊部分がクリープ的応力を受けた場合 の上限降伏応力 $\tau_{u}$ についての実験を行なった。一般に 未破壊部分の強風化層は過圧密粘性土であり, 地すべり 面の深度が浅いため土かぶり応力も小さい。また被圧的 間げき水圧は長時間にわたって一定値が作用するわけで はないが，これによって有効応力が減少する形態にな る。したがって上記の諸条件にもとづく試験は厳密な意 味でのクリープ試験ではない。実験方法の詳細について は既に発表7) しているので省略するが，図-8に示した ように試料を $p_{y i}$ で压密し, 垂直応力を $p_{0 i}$ に減少させ て過圧密形式にした後一定の水平応力 $\tau_{i}$ (クリープ的応 力）を加え，その後垂直有効応力を段階的に減少させる 方式 (水平変位速度が零になる毎に) によって $\tau_{i}$ と $p_{e}$ の関係を求めたもので, 図-8の矢印は, 垂直応力の変 化状態を示したものである。この結果は垂直有効応力 $p_{e} \leqq 1.0 \mathrm{~kg} / \mathrm{cm}^{2}$, 特よび含水比がほぼ一定の試料につい て, $\tau_{u}$ と $p_{e}$ との間に,

$$
\tau_{u}=c_{c}+p_{e} \cdot \tan \phi_{c} \cdot
$$

なる関係がえられた。定数 $c_{c}, \phi_{c}$ を粘着 力, 内部摩擦角と同じ意味に解釈すると, 式 (4) はクーロン式と同じ形式になる。未 破壊部分の破壊は式 (3) で示した最大主応

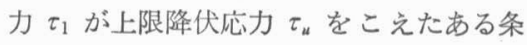
件のもとで発生する。

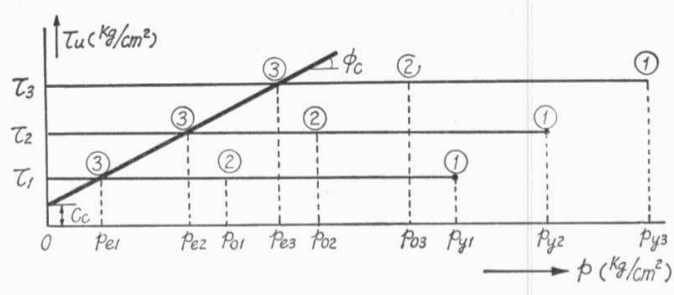

図-8 $\quad c_{c}, \phi_{c}$ の測定方法と応力経歴

つぎに未破壞部分に働く垂直方向の有効応力は,

$$
\sigma_{y}=p_{e}=\left(\gamma h \cos ^{2} \theta_{w}-\gamma_{w} h_{w} \cos \theta_{w}\right) \cdots \cdots \cdots \cdots \text { (5) }
$$

ここで, $\gamma$; 主として第 I 層単位体積重量, $h$; 潜在す ベり面までの平均深さ, $\theta_{w}$; 潜在すべり面の平均傾斜, $h_{w}$; 潜在すべり面上の地下水深（被圧地下水の水頭を水 深として表示する), $\gamma_{w}$; 水の単位体積重量, とする(図 -7 参照)。一方, 水平方向の応力 $\sigma_{x}$ については

$$
\sigma_{x}=\left(\gamma h=\gamma_{w} h_{w}\right) K_{n} \cdot \cos \theta_{w} \cdot \cdot
$$

が作用すると考える。ここで $K_{n}$ は静止土圧係数とする。 また有効応力の減少に伴い潜在すべり面に発生する単位 長あたりのせん断応力は次式で表わされる8 。

$$
\begin{aligned}
\tau_{x y} & =\left\{\Sigma W \sin \theta_{w}+P_{A}+K_{d} \cdot L \cdot \gamma_{w} \cdot h_{w} \cdot \tan \phi_{c}\right. \\
& -c_{w}\left(1-K_{d}\right) L-c_{c} \cdot K_{d} \cdot L \\
& \left.-K_{d} \Sigma W \cos \theta_{w} \cdot \tan \phi_{c}-P_{p}\right\} / K_{d} \cdot L \cdots \ldots \ldots . .
\end{aligned}
$$

式 (3) と式 (4) から未破壊部分の破壊条件として

$$
\begin{aligned}
& 2\left(c_{c}+p_{e} \cdot \tan \phi_{c}\right)<\sqrt{\left(\sigma_{x}-p_{e}\right)^{2}+4 \tau_{x y}{ }^{2}} \\
& \left(c_{c}+p_{e} \cdot \tan \phi_{c}\right)^{2}<\left(\frac{\sigma_{x}-p_{e}}{2}\right)^{2}+\tau_{x y}{ }^{2} .
\end{aligned}
$$

が得られる。上式に式（5）（7）の数式を代入すると, 式（8）は未破壊部分がクリープ的破壞をおこすために必 要なせん断応力と $h_{w}$ との関係を表わす式になり, これ は $h_{w}$ の関数になるから, 解いて得られた $h_{w}$ 以上の地 下水深（被圧水頭）になったときに新規の地すべりが発 生することになる。

\section{3 口之津地区における新規地すべりの発生}

以上の考察結果にもとづき之津町上大抜地内の新規 地すべり発生機構について検討する。この地内は地すべ り面の平均深度 $h=3.79 \mathrm{~m}$, 地すべり面長 $L=85.3 \mathrm{~m}$, 口之津地区では中規模の表層地すべりで, 図-9 と表- 3 に地内の断面図と必要数值とを示した。この地内は平常 時 $h_{w}=0$ であるから (表- 1 参照), このときの安全率は 
地すべり Vol. 14, No. 3 (通巻 第51号)

表-3 上大拔地区地すべり部分の諸数値

\begin{tabular}{c|c|c|c|c}
\hline \hline $\begin{array}{c}L \\
(\mathrm{~m})\end{array}$ & $\begin{array}{c}\sum W \sin \theta \\
(\mathrm{t})\end{array}$ & $\begin{array}{c}W \cos \theta \\
(\mathrm{t})\end{array}$ & $\begin{array}{c}\theta_{w} \\
(\mathrm{deg})\end{array}$ & $\begin{array}{c}h \\
(\mathrm{~m})\end{array}$ \\
\hline 85.3 & 133.35 & 586.48 & 12 & 3.79 \\
\hline
\end{tabular}

表-4 上大抜地区，地すべり面付近の 地層の物理的, 力学的両性質

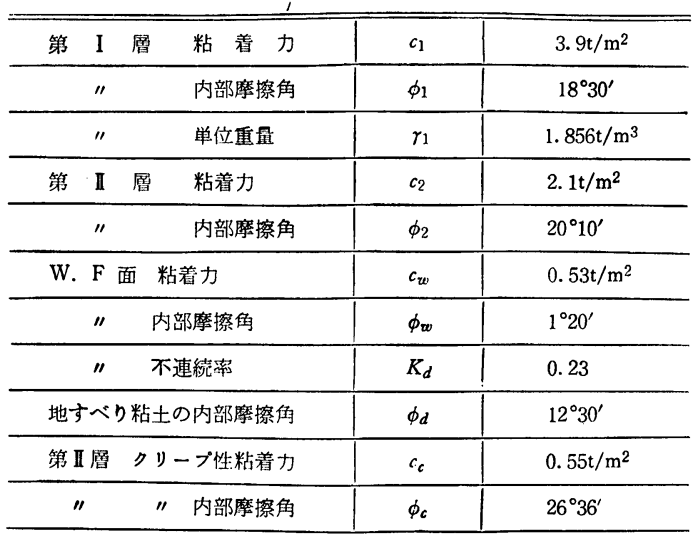

（注） W.F 面：water film 面

つぎの式で表わされる9)。

$$
\begin{gathered}
F_{s}=\left\{c_{w}\left(1-K_{d}\right) L+c_{2} K_{d} \cdot L\right. \\
\left.+K_{d} \tan \phi_{2} \cdot \Sigma W \cos \theta_{w}+P_{p}\right\} \\
\quad /\left(\Sigma W \sin \theta_{w}+P_{A}\right) \cdots \cdots \cdots . . \\
\left.P_{p}\right\}=\frac{\gamma_{1} h_{1}^{2}}{2} \tan ^{2}\left(45 \pm \frac{\phi_{1}}{2}\right) \\
\quad \pm 2 c_{1} h_{1} \tan \left(45 \pm \frac{\phi_{1}}{2}\right)
\end{gathered}
$$

（10）（符号同順）

式（9）に拈ける各数值の測定法はすでに報告したが, 表-4の結果が得られている。式（10）によって主働土 压 $P_{A}<0$, 受働土圧 $P_{p}=27.0 \mathrm{t} / \mathrm{m}$ になるので安全率は

$F_{s}=(34.81+41.20+66.42+27.00) / 133.35=1.27$ 飞なり平常時 $\left(h_{w}=0\right)$ は安定している。

ここで，潜在すべり面に作用する最大主せん断応力 $\tau_{1}$ が，この面のクリープ的上限降伏応力 $\tau_{u}$ に達するに 必要な間げき水圧を，地べり面上の平均地下水樑 $h_{w}$ に 換算して求めてみる。式 (7) 飞表- 3 , 表- 4 の数值を代 入して,

$\tau_{x y}=\left\{133.35+0.23 \times 85.3 \times \tan 26^{\circ} 36^{\prime} \times h_{w}\right.$

$-0.53(1-0.23) \times 85.3-0.55 \times 0.23 \times 85.3$

$\left.-0.23 \times 586.48 \times \tan 26^{\circ} 36^{\prime}-27.00\right\} / 0.23 \times 85.3$

$=0.5 h_{w}-0.342$

式（5）に表- 3 ，表- 4 の数值を代入すると

$p_{e}=1.856 \times 3.79 \times \cos ^{2} 12^{\circ}-1 \times h_{w} \cos 12^{\circ}$

$=6.730-0.978 h_{w}$

$\sigma_{x}=\left(1.856 \times 3.79-1 \times h_{w}\right) \times 0.7 \times \cos 12^{\circ}$

$=4.816-0.685 h_{w}$

ここで静止土圧係数は, 過圧密比 2 程度の粘性土の場
合として 0.7 の数值を用いる ${ }^{11)}$ 。

$$
\sigma_{x}-p_{e}=0.293 h_{w}-1.914
$$

図-8に示したようにクリープ的せん断試験の結 果か ら上限降伏応力 $\tau_{u}$ は

$$
\begin{aligned}
\tau_{u} & =0.55+p_{e} \cdot \tan 26^{\circ} 36^{\prime} \\
& =0.55+\left(6.730-0.978 h_{w}\right) \times 0.5 \\
& =3.915-0.489 h_{w}
\end{aligned}
$$

以上の数式を式（8）の破壊条件式に代入すると

$\left(3.915-0.489 h_{w}\right)^{2}<0.25\left(0.293 h_{w}-1.914\right)^{2}$

$+\left(0.5 h_{w}-0.342\right)^{2}$

$h_{w}{ }^{2}+100.3 h_{w}-446.68>0$

の $h_{w}$ についての二次式が得られる。これから $h_{w}>$ $4.27 \mathrm{~m}$ が求むるが, $h_{w}>h=3.79 \mathrm{~m}$ の状態は被圧的間げ き水圧が作用することを意味し，新規地すべり発生時の 自噴現象を裏付ける。このときつぎの比率を考兄， $h_{w}=$ $4.27 \mathrm{~m}$ を式（11）に代入すると。

$$
\begin{aligned}
F_{s}= & \left\{c_{w}\left(1-K_{d}\right) L+c_{c} \cdot K_{d} \cdot L\right. \\
& +K_{d} \cdot \tan \phi_{c} \Sigma W \cos \theta_{w}+P_{p} \\
& \left.-K_{d} \cdot L \cdot \gamma_{w} \cdot h_{w} \cdot \tan \phi_{c}\right\} / \Sigma W \sin \theta_{w}
\end{aligned}
$$

$$
F_{s}=(34.81+10.79+67.45+27.00-41.89)
$$

$/ 133.35=0.736$

の状態に招いて潜在すべり面がクリープ的破壊を打こす 条件に達する。式（11）は安全率ではなく，このときの 状態を慣行に従って比率形式で表わしたものあるが, 新 規地すべりの発生機構を示すものとしていろいろな意味 をもっている。

一方, $h_{w}=4.27 \mathrm{~m}$ の水頭に相当する被圧間げき水圧が 潜在すべり面に作用したときの有効応力は, 式 (5) から

$$
p_{e}=1.856 \times 3.79 \times \cos ^{2} 12^{\circ}-1.0 \times 4.27 \times \cos 12^{\circ}
$$$$
=2.55 \mathrm{t} / \mathrm{m}^{2}
$$

このときの上限降伏応力, 最大主応力を計算すると

$$
\begin{aligned}
\tau_{u} & =0.55+2.55 \times \tan 26^{\circ} 36^{\prime}=1.83 \mathrm{t} / \mathrm{m}^{2} \\
\tau_{x y} & =\left(0.5 h_{w}-0.342\right)=0.5 \times 4.27-0.342 \\
& =1.79 \mathrm{t} / \mathrm{m}^{2} \\
& \left(\sigma_{x}-p_{c}\right)^{2}=(0.293 \times 4.27-1.914)^{2} \\
\tau_{1}= & 0.5 \sqrt{(0.293 \times 4.27-1.914)^{2}+4 \times 1.79^{2}} \\
= & 1.82 \mathrm{t} / \mathrm{m}^{2}
\end{aligned}
$$

したがって $h_{w}>4.27 \mathrm{~m} ， \tau_{1}>\tau_{u}$ の状態が，ある時間続 いたとき，未破壊部分がクリープ的な破壊を括こして water film 面を含さ連続した破壊面になり，新規の地す ベりが発生する。このとき破壊面の角度 $\theta$ は,

$$
\tan 2 \theta=\left(p_{e}-\sigma_{x}\right) / 2 \tau_{x y}
$$

$\tan 2 \theta=(2.55-1.89) / 2 \times 1.79=0.1844$

によって, $2 \theta=10^{\circ} 27^{\prime}, \theta_{1}=5^{\circ} 13^{\prime}, \theta_{2}=95^{\circ} 13^{\prime}$ の二方向 があるが，テストピットによる観察の結果，水平面と $18^{\circ}$ 前後の角度をなす破壊面が見いだされ，計算結果と ほぼ一致することが実証できた（図-10 参照）。 


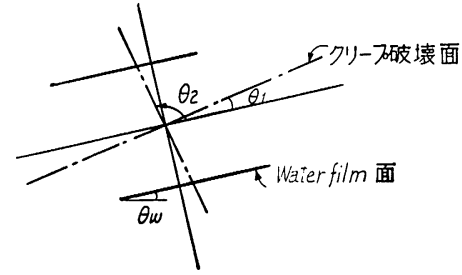

図-10末破壊部に発生するクリープ性破壊面

この例では被生地下発生層内の間げき水王の水頭が潜 在すべり面の平均深度 $h$ の 1.13 倍に達し, 潜在すべり 面の有効応力と上限降伏応力とを著しく低下させ，この 面のクリープ的破壊を誘発して地すべりを発生させてい るが，被生的間げき水圧は長時間持続する性質のもので はない。裴-1の地下水位変動状況を見ると，2.2. (1)の ところで述べた降雨量があったときには，1日程度の閒 げき水压が持続するよらである。クリープ的破壊に要す る時間は， $\tau_{1} / \tau_{u}$ の比に関係し，これが大きい程短時間 で破壊する。

\section{4 口之津地区における再発地すべりの発生}

新規の表曆地すべりが発生した後，逨続したすべり面 （破壊面）に沿って䔦い擦過粘土（地すべり粘土）が生 成するが，これの力学的性質は圧密状態によって変化す ることを指摘した ${ }^{12)}$ 。新規滑動が間げき水王の消失によ って停止すると，擦過粘土は $c_{d} \fallingdotseq 0, \phi_{d}>0$ の正規王密 状態になるので, $h_{w}=0$ のとき安全率はつぎのように なる(3)。

$$
F_{0}=\tan \phi_{d} \cdot \Sigma W \cos \theta_{w} / \Sigma W \sin \theta_{w} \cdots
$$

上大拔地内の場合, 滑動停止後（压密終了後）の内部 摩擦角は表- 4 によって $\phi_{d}=12^{\circ} 30^{\prime}$ であるから

$$
F_{s}=0.2217 \times 786.44 / 133.35=1.31
$$

この数佔は間げき水正が作用しないときの潜在すべり 面の安全率にほぼ等しく，安定を保っている。新規滑動

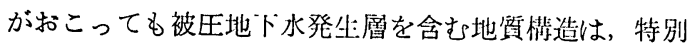
な状態が扣こらない限り特に变化しないので，ある降雨 盐ごとに間げき水圧を発生し，式（14）の分子の值が娍 少する形式で安定が崩れて再滑動を開始する。

$$
F_{s}=\frac{\tan \phi_{d} \Sigma\left(W \cos \theta_{w}-u_{\imath}\right)}{\Sigma W \sin \theta_{u}}
$$

$$
\text { ここで } \begin{aligned}
\Sigma W \sin \theta_{w} & =\tan \phi_{d} \Sigma W \cos \theta_{w} \\
& -\tan \phi_{d} \cdot \gamma_{w} h_{w} \cdot L
\end{aligned}
$$

と值いてすべり面の均衡が崩れるときの平均水深 $h_{w}$ (ま たは被纴䦌げき水压 $u_{i}$ ) を求めると

133. $35=0.2217\left(786.44-1 \times 85.3 \times h_{w}\right)$

によって $h_{w} \geqq 2.17 \mathrm{~m}$ に扣いて再滑動が発生し, 新規滑
動の場合に比較すると $1 / 2$ 程度の間げき水王が地すべり 面に作用すればよく、これが降雨によって繰返される再 発地すべりの発生機構である。

\section{4: あとがき}

ある条件のもとで被压的間げき水压が発生する特殊な 地質檴造, 有効応力が減少する過程に拈ける過珐密粘性 土のクリープ的上限降伏応力の低下現象, これらをもと にロ之津地区に扣ける新規の表層地すべりの発生機構を 解析し，新規地すべり発生時の自噴現象，逃続した地す ベり面の複合波状構造を理論的に榆討した。さらに 150) $\mathrm{mm}$ 前後の降雨量によって断続的に発生する再滑動機槛 との門連性についても考察を加えた。

この結果, 新規, 再滑動兩地すべりとも, 潜在すべり 面または地すべり面に対して，一定值以上の間げき水圧: が作用した場合に地すべりが発生するが，上大拔地内で は解者の埸命には，後者の場合に此恼して 2 倍程度の間 げき水生を必要とすることが判明し，これらの数值を推 定することが可能になった。だが新規地すべりの埸合, 発生:地内を予和して間げき水圧計を設圈，钼測すること は不可能に近く，被压的間げき水圧を間接的方法によっ て推定せざるを得なかったこと，再滑動地すべりの場合 動的間げき水圧が作用し14), 安全率 1.0 に拈いて滑動す るとは限らないこともあって, 理論任よりも若干大きい 值が測定されているなと，钼測修を主体とした根拠に欠 けることが不馓な点として残されている。

\section{参考文 献}

1）玉田文玨：口之津地すべりのすべり面形成過程について(I) $\sim(\mathbb{I})$, 地すべり, Vol. 7, No.4, Vol. 8. No. 1, Vol.8, No. 2 ,

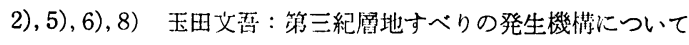
土と基礎, Vol, 21, No. 8,

3),4）银崎紧林業コンサルタント：口之津地区地すべり調查報 告㫪, 昭和 $46 \sim 48$,

7）玉时文吾，保永雄二：粘性土のせん断応力によるクリープ破 壞機構について, 西日本工蛪大学紀要, Vol. 6 (1976),

9), 10）玉田文吾, 地すべり面の力学的性質と土質試験法につい て (I ) (II), 地すべり, Vol. 11, No. 1, Vol.11, No. 2,

11）山内費聡，安原一哉：粘性土の静止土圧係数に関する一考察 土質工学会論文報告集, Vol. 14, No. 2, (1974)

12),13）玉田文吾, 前田面人：新切地区に拈けるせん断特性の変 化について，地すへりり，Vol. 11，No.4,

14）玉田文吾，前田重人：長崎罧平山地すべり地区の降雨による 滑動機槛，地すべり，Vol. 12, No.2 （原稿受理日 昭和 52 年 8 月 23 日） 


\section{ロ之津地区における表層地すべりの発生機構}

「地すべり」Vol. 14, No. 3 (通巻 第51号) 1977年（昭和52年）12月

玉王文吾

長崎県口之津地区にはすべり面の浅い新規扰よび再滑動型の表層地すべりが発生する。これを，降雨によって被 压間げき水圧を発生する特殊な地質構造と潜在地すべり面粘性土の有効応力減少にともなって生しるククープ的破 壊機满との関係に扎いて解明し, 上大拔地内の新規地すへりについては, 地すべり面深度に等しい地下水深の約 1.1 倍に相当する被圧的間げき水压によって, 再滑動地すべりについてはこれの $1 / 2$ 程度の間げき水压によって誘 発されることを指摘した。

\section{鉛直方向側面破壊の検討 II —その実例—}

「地すべり」Vol. 14，No.3 (通巻 第51号) 1977年（昭和52年）12月

佐々 恭二, 武居 有恒

地すべり，斜面崩壊など斜面不安定化の機構としてはこれまで地すべり底面においてセン断力がセン断抵抗力よ り大きくなり，斜面方向に動き出すと言うものが考えられて来た。ところが室内実験, 現地調查の結果, 上記の機 構とは異なり，土層がまず鈶直沈下を起し，それによって土塊が流動化したり，あるいは側面のセン断抵抗力減少 によってすべり出す場合があり得ることに気ついた。鉛直方向側面破壊の検計ー IIはこの問題を現地調查の面かに 実例をあげて検証したものである。

\section{第三紀層神戸層群における農地地すべりに関する研究}

第 3 報神戸市善入沢田池集水域における地形と土地利用区分の特性について

「地すべり」Vol. 14, No. 3 (通巻 第51号) 1977年（昭和52年）12月

石田 陽博, 川原 敏宏, 幸行

自然現象の中，特に地表に対する自然災害は人間生活に与える影㗽が大きい。地形はその上に載る人間生活の地 表的表現である土地利用とも密接な関係を持っている。

第 3 報は第 2 報と同㥞の目的・方法で神戸市善入地区沢田池集水域の地形と土地利用区分の特性を研究した。こ こでる西畑・西篻等と類似の地形的特性を見出したが，地表斜面の上方で谷・星根の判別が困難なことと稜線付近 における数個の重箱池の存在が特徵的であった。 